\title{
Effect of Processing Time and Concentration of Potassium Permanganate on Physico-Mechanical Properties of Denim Jeans During Stone Washing
}

\author{
Elias Khalil \\ Department of Textile Engineering, World University of Bangladesh, Dhaka, Bangladesh
}

Email address:

eliaskhali152@gmail.com (E. Khalil)

\section{To cite this article:}

Elias Khalil. Effect of Processing Time and Concentration of Potassium Permanganate on Physico-Mechanical Properties of Denim Jeans During Stone Washing. Science Innovation. Vol. 3, No. 6, 2015, pp. 68-71. doi: 10.11648/j.si.20150306.12

\begin{abstract}
Three 100\% cotton denim jeans were treated with stone acid wash with the variation of processing time $(1.5,2 \& 2.5$ minutes) and concentration $(1.5,2 \& 2.5 \mathrm{~g} / \mathrm{l})$ of potassium permanganate after typical enzyme bleach wash. Various physical and mechanical properties (Hand feel, Weight, EPI, and PPI, Tensile strength, Shrinkage, Seam strength, Count \& stiffness) were investigated before and after each treatment (concentration and respective time) according to standard test methods. It was found that change in processing time and concentration reveals big difference in various properties between treated and untreated garments.
\end{abstract}

Keywords: Potassium Permanganate, Processing Time, Physical and Mechanical Properties, Stone Acid Wash, Denim Jeans

\section{Introduction}

Among all the textile products, no other fabric has received such a wide acceptance as denim Jeans [1]. It can be considered as the most widely used garment in the fashion business. It is well known that denim and jeans have had a major influence on the lives of consumers since their inception. Jeans have become symbols for cowboys, women, youth and economic status. Through the ages, jeans have evolved from work wear to casual wear and then to premium wear and functional wear. Consumers evaluate jeans based on style, brand, country of origin and company ethics. As with any other apparel, denim garment companies target specific market segments, however, no other garment can claim the social culture that denim has already set. Designer jeans as well as premium jeans first influenced a small group of luxury consumers, but now consumers from all social and economic classes embrace them. Challenges faced by denim apparel manufacturers and fashion designers include the need for reinventing products for niche markets, and meeting consumer demands for better apparel sizing [2].

Denim Jeans washing is a novel process to impart worn-out look, to modify the appearance and to improve the comfort ability of the garments [3]. It is one of the finishing methods applied on garment, with the use of new technolo- gies and equipment enables to obtain the desired results [4]. Recently, textile manufacturers start fading i.e. discoloration on shade of denim jeans which become very popular amongst young customers [5].Therefore, companies have been trying in recent years to develop various techniques to improve the visual aspect of fabrics especially the faded looks [6-8].

Potassium permanganate is an inorganic chemical compound with the chemical formula $\mathrm{KMnO}_{4}$ [9]. It is a strong oxidizing agent and used to make color fading effect on denim jeans [10-12]. Sometimes it is used at the point of hand sand area or without hand sand area. Though it is a great oxidizing agent, after applying it is necessary to neutralize the garments by any good neutralize agent [13].

Xiang-Rong Xu et al. (2005) experimented decolorization of dyes and textile wastewater by potassium permanganate and found that Concentration of potassium permanganate and temperature had significant effects on the decolorization efficiency [14].

Jiming Yao et al. (2013) investigated the effects of potassium permanganate decoloration on denim shade. The results showed that the brightness of denim generally was enhanced by increasing processing time, $\mathrm{KMnO}_{4}$ and $\mathrm{H}_{3} \mathrm{PO}_{4}$ concentrations [15].

However, the effect of change in concentration of $\mathrm{KMnO}_{4}$ and processing time on physico-mechanical properties was not studied in the past research. These two parameters play 
important role on $\mathrm{KMnO}_{4}$ oxidation which further affect denim performances.

In this present study, three kinds of denim jeans dyed by indigo were treated using different concentration of $\mathrm{KMnO}_{4}$ with constant amount of $\mathrm{H}_{3} \mathrm{PO}_{4}$ solutions with different processing time and changes of physical and mechanical properties were recorded and evaluated.

\section{Materials and Methods}

\subsection{Materials}

$100 \%$ cotton denim jeans were used. These comprised indigo dyed denim fabric, GSM (Grams per Square Meter) 310, $3 / 1$ warp faced twill, construction $72 \times 40 / 12 \times 11$, fabric width 57 inch.

Genzyme SL (a cellulase enzyme, Sri Lanka); Jet (an anionic detergent, Bangladesh); Bio.D. (a desizing agent, Germany); soda ash (China), acetic acid (China), Bleaching powder (KCI bleach, India); Sodium Meta bisulphite (India), Sodium hyposulphite (India), Potassium permanganate, phosphoric acid (laboratory grade) were used for this experiment. The fresh pumice stones (Turkey) of medium size $(3-5 \mathrm{~cm})$ were used for soaking.

\subsection{Desizing}

The desizing was conducted in liquor containing soda ash $(1.2 \mathrm{~g} / \mathrm{l})$, detergent $(0.6 \mathrm{~g} / \mathrm{l})$, and desizing agent $(0.6 \mathrm{~g} / \mathrm{l})$ and material to liquor ratio of $1: 30$ in an industrial horizontal sample washing machine (Ngai Shing, model-NS 2205, Hong Kong) at temperature $60^{\circ} \mathrm{C}$ for $20 \mathrm{~min}$. After that washed with hot water $\left(70^{\circ} \mathrm{C}\right)$ followed by cold water $\left(40^{\circ} \mathrm{C}\right)$ wash.

\subsection{Enzyme (cellulase) Treatment}

The process was conducted in liquor containing acetic acid $(1.0 \mathrm{~g} / \mathrm{l})$ at $\mathrm{pH} 5.5$ and material to liquor ratio of $1: 30$ with cellulase in the washing machine. The process was carried out at concentration of Genzyme SL of $2 \%$ at $45^{\circ} \mathrm{C}$ temperature for $30 \mathrm{~min}$. After desired time the temperature was raised to $90^{\circ} \mathrm{C}$ for 1 min to stop enzymatic action then washed with hot distilled water followed by cold $\left(40^{\circ} \mathrm{C}\right)$ distilled water.

\subsection{Bleaching Treatment}

Enzyme treated denim trousers were then treated using bleaching powder. This process was conducted in liquor containing KCI bleach $(10 \mathrm{~g} / \mathrm{l})$, soda ash $(5 \mathrm{~g} / \mathrm{l})$ at $\mathrm{p}^{\mathrm{H}} 10.5$, and material to liquor ratio of $1: 10$ in the washing machine. The bleach treatment was carried out at $50^{\circ} \mathrm{C}$ temperature and treatment time was $30 \mathrm{~min}$. The denim garments were then neutral washed with Hypo $(2 \mathrm{~g} / \mathrm{l})$ for $5 \mathrm{~min}$ at $40^{\circ} \mathrm{C}$. The garments were rinsed in cold water.

\subsection{Acid Washing}

Pumice stones (4.6 owg) are first presoaked in three solutions comprised of different concentration of $\mathrm{KMnO}_{4}(1.5,2.0$,
$2.5 \mathrm{~g} / \mathrm{l})$ and constant amount of $\mathrm{H}_{3} \mathrm{PO}_{3}(2 \%)$ and then place the stones in a rotary tumble washing machine along with 'waste' fabric and tumbling for several minutes to remove the excess solution. Then three denim garments are washed separately for 1.5, $2.02 .5 \mathrm{~min}$. Then Rinse to remove stone dust and finally neutralizing (with Sodium Meta bisulphite), hydro extracting and drying were done.

\subsection{Testing and Analysis}

Treated all denim trousers were conditioned in $65 \% \mathrm{RH}$ and $20^{\circ} \mathrm{C}$ for $24 \mathrm{~h}$ before testing according to BS EN 20139 and ASTM D1776 [16].Tensile strength was determined by the US Standard Grab test method according to ASTM D 5034 [17]. Dimensional changes / shrinkage (\%) was calculated from the difference in fabric length before and after washed garment according to AATCC test methods 135 and 150; ASTM D 2724, BS 4931 [18].GSM was calculated from the differences in denim fabric weight between before and after washed treated denim according to ASTM D 3776 [19].Stiffness was measured from the bending rigidity in fabric by Shirley stiffness tester according to BS 3356 [20].Seam Strengths were measured by following ASTM D 1683 [21].

\section{Results and Discussions}

In this experiment, the effect of different conc. of potassium permanganate ( 1.5 to $2.5 \mathrm{~g} / \mathrm{l})$ and processing time $(1.5$ to $2.5 \mathrm{~min}$ ) on the properties of denim garments during acid washing was investigated. It can be seen from the Table 1 that treatment of denim trouser with Potassium permanganate at $1.5 \mathrm{~g} / 1$ concentration cause significant decrease $(2.22 \%)$ of tensile strength (also seam strength) and this decrease was higher at higher PP concentrations $(2.5 \mathrm{~g} / 1)$ and higher processing time $(2.5 \mathrm{~min})$ in both warp and weft direction. PP decomposed cotton under the conditions used. PP first attacked on dyed yarn portion, decomposed them slowly and fibers are partly degraded from the yarn chain (which is responsible for being finer yarn count and decreasing fabric weight) and step by step penetrated inside fabric. Therefore, the chemical bonds of primary wall (outer layer) are broken by the decomposition of the aqueous solution of PP. After that it attacked on secondary wall. The result of this reaction is that the primary wall (outer layer) of the cotton fiber is loosened and broken down quicker with the frictional action (mechanical forces) of rotating cylinder of the washing machine and rough surface of stone that works as an abradant in washing cycle.

Denim decomposition by measuring the stiffness from denim garments was monitored. As evident, the stiffness of the denim garment decreased $(12.37 \%)$ at $1.5 \mathrm{~g} / 1$ concentration significantly after treatment with PP, and the decrease was more $(30.27 \%)$ pronounced at higher PP concentration and processing time up to $2.5 \mathrm{~g} / 1$ and 2.5 min respectively. By PP treatment, the cotton fibers are loosened due to fibrils are degraded and partly detached from the main fiber chain, and softness increased. After treatment with PP, the sizes (starch) of warp yarns were removed. As a result bending length was 
less and softness was increased. When the denim garment was thoroughly wetted in PP washing, it tended to revert its more stable dimensions which results in the contraction of the yarns. This effect is usually greater in the warp direction than in the weft direction. This is known as relaxation shrinkage [22].

Due to relaxation shrinkage, PPI (picks per inch) and EPI (ends per inch) was increased than untreated denim garments.

Table 1. Change in physical and mechanical properties of denim jeans with variation of processing time and concentration of potassium permanganate.

\begin{tabular}{|c|c|c|c|c|c|c|}
\hline \multirow{2}{*}{\multicolumn{3}{|c|}{ Properties of denim Jeans }} & \multirow{3}{*}{$\begin{array}{l}\text { Before Wash } \\
12\end{array}$} & \multicolumn{3}{|l|}{ After Wash } \\
\hline & & & & \multirow{2}{*}{$\begin{array}{l}\mathrm{KMnO}_{4} \text { Conc. } 1.5 \mathrm{~g} / \mathrm{l} \\
\text { Time } 1.5 \mathrm{~min} \\
13\end{array}$} & \multirow{2}{*}{$\begin{array}{l}\mathrm{KMnO}_{4} \text { Conc. } 2.0 \mathrm{~g} / \mathrm{l} \\
\text { Time } 2.0 \mathrm{~min} \\
13\end{array}$} & \multirow{2}{*}{$\begin{array}{l}\mathrm{KMnO}_{4} \text { Conc. } 2.5 \mathrm{~g} / \mathrm{l} \\
\text { Time } 2.5 \mathrm{~min} \\
14\end{array}$} \\
\hline \multirow{2}{*}{ Count $(\mathrm{Ne})$} & \multicolumn{2}{|c|}{ Warp Yarn } & & & & \\
\hline & \multicolumn{2}{|c|}{ Weft Yarn } & 11 & 12 & 12 & 13 \\
\hline \multirow{2}{*}{ Shrinkage (\%) } & \multicolumn{2}{|c|}{ Lengthwise } & 0 & -3.5 & -4 & -4.5 \\
\hline & \multicolumn{2}{|c|}{ Widthwise } & 0 & 1.5 & 1.75 & 2.25 \\
\hline Tensile Strength (lbf) & \multirow{2}{*}{\multicolumn{2}{|c|}{ Weft Way }} & 340 & 300 & 280 & 275 \\
\hline EPI & & & 72 & 73 & 75 & 76 \\
\hline PPI & & & 40 & 43 & 45 & 47 \\
\hline GSM & & & 310 & 297 & 290 & 282 \\
\hline \multirow{2}{*}{ Seam Strength (\%) } & \multicolumn{2}{|c|}{ Warp way } & 100 & 65 & 60 & 59 \\
\hline & \multicolumn{2}{|c|}{ Weft way } & 100 & 63 & 58 & 55 \\
\hline \multirow{3}{*}{ Stiffness (cm) } & Warp & Face & 3.88 & 3.40 & 3.22 & 3.20 \\
\hline & \multirow{2}{*}{ Weft } & Face & 2.33 & 2.31 & 2.25 & 2.25 \\
\hline & & Back & 2.73 & 2.65 & 2.63 & 2.62 \\
\hline
\end{tabular}

\section{Conclusion}

Due to strong oxidizing of $\mathrm{KMnO}_{4}$, physico-mechanical properties of denim changed obviously during acid stone washing. Along with increasing processing time and $\mathrm{KMnO}_{4}$ concentration, the number of released oxygen [O] increased and leading to enhance of oxidation ability that makes significant change in denim jeans properties. The tensile strength, seam strength, stiffness and fabric weight decrease after application of potassium permanganate with processing time during washing treatment while yarn count $(\mathrm{Ne})$, EPI, PPI and dimensional change increased.

\section{References}

[1] Khalil, E. (2015). Sustainable and Ecological Finishing Technology for Denim Jeans. AASCIT Communication, 2(5), 159-163.

[2] Paul, R. (2015). Denim and jeans: an overview. Denim: Manufacture, Finishing and Applications, Pp. 1-5.

[3] Sarkar, J., \& Khalil, E. (2014). Effect of Industrial Bleach Wash and Softening on the Physical, Mechanical and Color Properties of Denim Garments. IOSR Journal of Polymer and Textile Engineering, 1(3), 46-49.

[4] Khalil, E., \& Islam, M. M. (2015). Wrinkle Finish on Denim by Resin Treatment: A Review. AASCIT Communication, 2(3), 82-87.

[5] Card, A., Moore, M. A., \& Ankeny, M. (2005). Performance of garment washed denim blue jeans. AATCC review, 5(6), 28-31.

[6] Sariisik, M. (2004). Use of cellulases and their effects on denim fabric properties. AATCC review, 4(1), 24-29.
[7] Cavaco-Paulo, A. (1998). Mechanism of cellulase action in textile processes. Carbohydrate Polymers, 37(3), 273-277.

[8] Özdil, N., Özdoğan, E., \& Öktem, T. (2003). Effects of enzymatic treatment on various spun yarn fabrics. Fibres \& Textiles in Eastern Europe, 4 (43), 58-61.

[9] Potassium permanganate. (2015, September 2). In Wikipedia, the Free Encyclopedia. Retrieved 15:59, September 4, 2015, from

https://en.wikipedia.org/w/index.php?title=Potassium_perman ganate $\&$ oldid $=679056789$.

[10] Lin, L. X., 2009. Finishing of jeans clothing Dyeing Finish. 35 (18), 29-34.

[11] Zheng, Z. Q., 2009. A research on washing art effect of cowboy lining Shangdong Text. Econ. 2009-04 111-112, 115.

[12] Zhao, W. B., 2008. Common denim washing technologies (in Chinese). Dyeing Finish. 34 (7), 34-36.

[13] Rahman, M. S., (2014). Practical Handbook of Washing and Dyeing, Dhaka, University Campus Publishing, Pp. 73.

[14] Xu, X. R., Li, H. B., Wang, W. H., \& Gu, J. D. (2005). Decolorization of dyes and textile wastewater by potassium permanganate. Chemosphere, 59(6), 893-898.

[15] Yao, J. M., \& Wei, S. N. (2013, February). Effects of Potassium Permanganate Decoloration on Denim Shade. In Advanced Materials Research (Vol. 627, pp. 190-194).

[16] ASTM D 1776. (2008). Standard practice for conditioning textiles for testing. In American Society for Testing and Materials, Annual Book of ASTM Standards, Vol.07.01. West Conshohocken, PA, USA: ASTM International.

[17] ASTM D 5034. (2009). Standard test method for breaking force and elongation of textile fabrics (Grab test). In American Society for Testing and Materials, Annual book of ASTM Standards, Vol. 07.01. West Conshohocken, PA, USA: ASTM International. 
[18] AATCC test method 135. (2012). Colorfastness to laundering, home and commercial, accelerated. In American Association of Textile Chemists and Colorists. N. C., USA: Research Triangle Park.

[19] ASTM D 3776. (1996). Standard test methods for mass per unit area (weight) of woven fabric. In American Society for Testing and Materials, Annual book of ASTM Standards, Vol. 07.02. West Conshohocken, PA, USA: ASTM International.

[20] BS 3356. (1990). Method for determination of bending length and flexural rigidity of fabrics. Chiswick High Road, London, BSI Publisher.
[21] ASTM D1683 / D1683M-11a, Standard Test Method for Failure in Sewn Seams of Woven Apparel Fabrics, ASTM International, West Conshohocken, PA, 2011.

[22] Cookson, P. G., 1992, "Relationships between Hygral Expansion, Relaxation Shrinkage, and Extensibility in Woven Fabrics", Textile Res. J. 62: 44. 